\title{
Formalizing Domestic Tourism Sector in Sri Lanka: A Case Study on Southeast Dry Zone
}

\author{
M. Sunil Shantha ${ }^{1}$ \\ ${ }^{1}$ Department of Social Sciences, Sabaragamuwa University of Sri \\ Lanka,Belihuloya, shantha@sab.ac.lk
}

\begin{abstract}
Most countries in the world have gained economic advantages through tourism. They have implemented plans systematically for both domestic and international tourism sectors. In the recent world developed and developing countries have been taking more economic contribution from domestic tourism rather than from international tourism. Tourism industry in Sri Lanka is giving special attention to international tourism, but less attention to domestic tourism. The main objective of the study is to identify the recent salient features of the domestic tourism sector, analyzing the income expenditure patterns and the examining the possibility of introducing the tour package to the study area. The sample covers primary data from 200 domestic tourists and 100 related enterprises. The data analysis using simple regression analysis and it shows domestic tourists expenditure pattern has been change with formalizing the sector. In addition regional development, employment creation and income generation in the area was tremendously increased.
\end{abstract}

Key words: Tourism, income, expenditure, regional development

\section{Introduction}

In the recent world most countries have gained economic advantages through tourism. They have implemented plans systematically both in the domestic and international tourism sectors.

Countries like India, Bangladesh and the Maldives, which are in close proximity to Sri Lanka have modernized the industry obtaining economic benefits. The domestic tourism sector has, by and large, contributed to achieving the objectives of employment, economic growth, regional and rural development, income equality and enhancement of government revenue in these countries.

The domestic tourism sector had played a major role in the economic development of these countries. These countries have provided adequate infrastructure, and enhanced available facilities such as accommodation, food, transport, tour guiding, and other needs of the domestic tourism sector. 
The best example of a developed domestic tourism sector can be found in India (Shantha, 2000). It maintains the domestic tourism sector as an organised and widely recognized service in the country. The tourism related industries have shown a rapid growth. Tour packages including accommodation for both domestic and foreign tourists are available through a network of information and travel organisations. The tourism related industries and services contribute to the economy of the country by enhancing the profits of the domestic tourist sector. "The recent studies by United Nations' Development Programme (UNDP) and World Tourism Organisation (WTO) have recognized the importance of the development of the domestic tourism sector. It has been revealed that a high portion of the foreign revenue earned by the international tourism sector is in turn absorbed by the same countries" (Bhathia, 1978).

Modern tourism as an industry developed only after the 1960's in Sri Lanka when the government recognised it as a key industry in economic development.

Today the tourist industry contributes about 1.9\% to the GNP and $5.2 \%$ to foreign earnings of Sri Lanka. The net earnings become less because of the heavy dependence on imports (Central Bank of Sri Lanka, 2005).

The amount of import composition of the tourism sector of Sri Lanka has reached a level close to $50 \%$ of imports. Because of most of international tourist needs defended on the heavy importations. The value added to the economy by the foreign tourism sector is less than $50 \%$. However, the domestic tourism sector is able to contribute a higher value added factor to the national economy than the international tourism sector. This is because a high amount of foreign revenue is not siphoned off to foreign countries for the provision of imported food and beverages, luxury items and equipment, and transport to satisfy requirements and standard of foreign tourists. The need for recognizing the domestic tourism sector as a vital facet of our economy is crucial to the country and in particular to the tourist industry.

Bull (1992) has discussed the question of the direct value of domestic tourism to the GNP. "Within an economy, domestic tourism expenditure normally counts as part of $C+I$ (Consumption and Investment) and therefore is principally a reallocation of consumers' or producers' spending from something else. It does therefore provide an injection of fresh demand and money" (Bull, 1992).

Among the factors contributing to the reallocate effects discussed by Bull (1992) are the opportunity use of the cash spent on tourism and the transfer of cash from high income generating areas to low income destination areas. According to Bull, a key to the value of domestic tourism is the opportunity 
use of cash spent by domestic tourists. He points out that if the alternative to foreign tourism were domestic tourism expenditure, domestic spending would be considered a form of import substitution reducing the leakage of imports (M) and actually increasing C + I. This, he argues, would directly benefit national income. The same would be true if the alternative to domestic tours were spending on domestic goods. If, rather than buying tourism, people bought goods and services at home, income and wealth would tend to be concentrated in the higher income locations, which generate tourists.

In addition, Bull (1992) points out that destination areas start with unemployment and comparatively low incomes, tourism could create employment and raise incomes, depending on the structure of the tourism labour market. Thus, there can be a reduction in government spending $(G)$ as social welfare payments are reduced. There may also be an increase in taxation revenue ( $\mathrm{T}$ ) from the tourism industry. At the same time depending on threshold tax rates, the opportunity use of tourists' expenditure may be adversely affected. In addition, marginal propensities to save may fall slightly, as tourists' spending transfer income to less well off recipients who would tend to have a higher propensity to consume.

According to the purpose of visits tourists were categorized into two groups by the (United Nations Conference on International Travel and Tourism in Rome, 1963)They are; International Tourist and Domestic Tourist.

International tourist is a temporary visitor staying at least 24 hours in a country visited whose motive for travel can be described as being either for: leisure (pleasure, holidays, health, study, religion or sport); or for business, family or work assignments (Francois and Lionel, 1995).

An individual who travels from place to place within the country for recreation, entertainment, cultural activities, business, health, sports, religious activities, education or any other purposes for a period of not less than 24 hours (Bull, 1992).

The study is focussed on the income and expenditure patterns of domestic tourists in Kataragama and Yala (these two places are located in Southeast Dry Zone in Sri Lanka) under present and future conditions. As the domestic tourism sector in Sri Lanka is informal at present it generates very few benefits to the economy of the location. It is identified that $70 \%$ of domestic tourists and pilgrims of all communities visit Kataragama and Yala (UNDP/WTO, 1993). The reasons for selecting Kataragama and Yala are that domestic tourists and pilgrims visit these places throughout the year and the development of the industry in these areas could be significant. Therefore, by formalising the industry, more benefits will accrue to low income regions, Kataragama and Yala. In addition, the value added to GNP will increase. 
Therefore, the income benefits received by the location through domestic tourism are evaluated to understand the extent to which reallocative effects discussed by Bull (1992) have occurred.

The growth of the domestic tourism sector in Sri Lanka has been unsystematic. Domestic tourists make annual tours throughout the country but there has not been a recognized program for them so far (Shantha, 2000). This has resulted in the lack of growth of the tourism backward linkage industries. Related industries are also not properly maintained. It is obvious that even the provisions of basic necessities for domestic tourists have been neglected. The institutions and industries located in the tourist attraction areas have shown an under-utilized capacity throughout the Island (Shantha, 2005).

There is a growth in the daily, weekend and annual tours by domestic tourists. Particularly, domestic tourists living in cities are interested in pleasure and weekend holidays, but due to the lack of necessary facilities available, the industry has been unable to absorb their potential tourist expenditure and thus enhance the economy. It is high time that the needs of middle and high-level income groups of tourists are adequately satisfied (Nakkawita, 1992).

According to survey the majority of domestic tourists arriving at the study area are from Colombo and other main cities of the island. Most of them are of middle class and high-income groups and their ability to spend is also at a high level. The number of tourist arrivals willing to spend an amount exceeding Rs. 5000 was $21 \%$, while those willing to spend between Rs. 2000 to 5000 were $46 \%$ in the location. The rest had the ability to spend less than Rs. 2000 on the tour.

The lack of proper programmes, the above amounts could not be spent, by the tourists during their tour in the location. Consequently the domestic tourism sector has not been able to provide a satisfactory contribution to the economy of the country the reason for the non-availability of Tour Packages to the domestic tourism in Sri Lanka.

There is a possibility of providing tour package systems to the two locations at varying and different costs, but so far sufficient attention has not been paid to this aspect. If implemented, it would definitely bring economic advantages to the region. A growth in the domestic tourist demand and service sectors could be made through the above programme. There would be a high level of contribution to regional development, growth of employment opportunities and the maximization of government revenue.

The major problems faced by domestic tourists and pilgrims arriving in the 
study area are lack of water, the mosquito menace, lack of cleanliness, lack of modes of transport, and difficulties in obtaining food and funding accommodation. In case of the industry related establishments, they are faced with problems arising from the lack of infrastructure facilities, limitation of land, influence of rules and regulations and institutional problems, which have slowed down the growth of this sector. This negligence has undermined the growth of the domestic tourism sector.

The domestic tourism sector can be stimulated to reach a significant level of economic activity with the effective implementation of a well planed system. Both state and private organizations related to the industry should co-operate to develop clear objectives.

\section{The Objectives of the Study}

The main objective of the study is how to formalizing domestic tourism industry in Sri Lanka through the case study of two tourist locations in the Southeast region of the country. The specific objectives of the study are;

a. Identifying the salient features of domestic tourism sector in the study area.

b. Analyzing the income expenditure patterns of domestic tourists and pilgrims by applying a regression model.

c. Examining the possibility of introducing the Tour Packages to cater to the requirements of domestic tourists.

d. Making recommendations to develop domestic tourism sector in the location.

\section{Methodology}

Information for the study was collected from existing literature as well as from field investigation. In addition to site visits, discussions and observations, two sample surveys were carried out in the study area in 2005 to gather information from (i) domestic tourists, (ii) tourists' establishments such as hotels, guesthouses and other tour operators and (iii) residents of the study area in the vicinity. Two questionnaires were adopted in these surveys: One questionnaire for domestic tourists and another questionnaire for tourists' establishments and local residents. The total number of respondents to the survey was 200 domestic tourists and pilgrims, 25 hotel owners, 15 caterers, 20 rest house and guesthouse owners, 10 private lodgings, 20 shop owners and 10 residents in the vicinity (Figure 1). Data will be analyzed through the application of regression analysis. 


\section{Results and discussion}

Domestic Tourist Arrivals to Kataragama and Yala by Districts

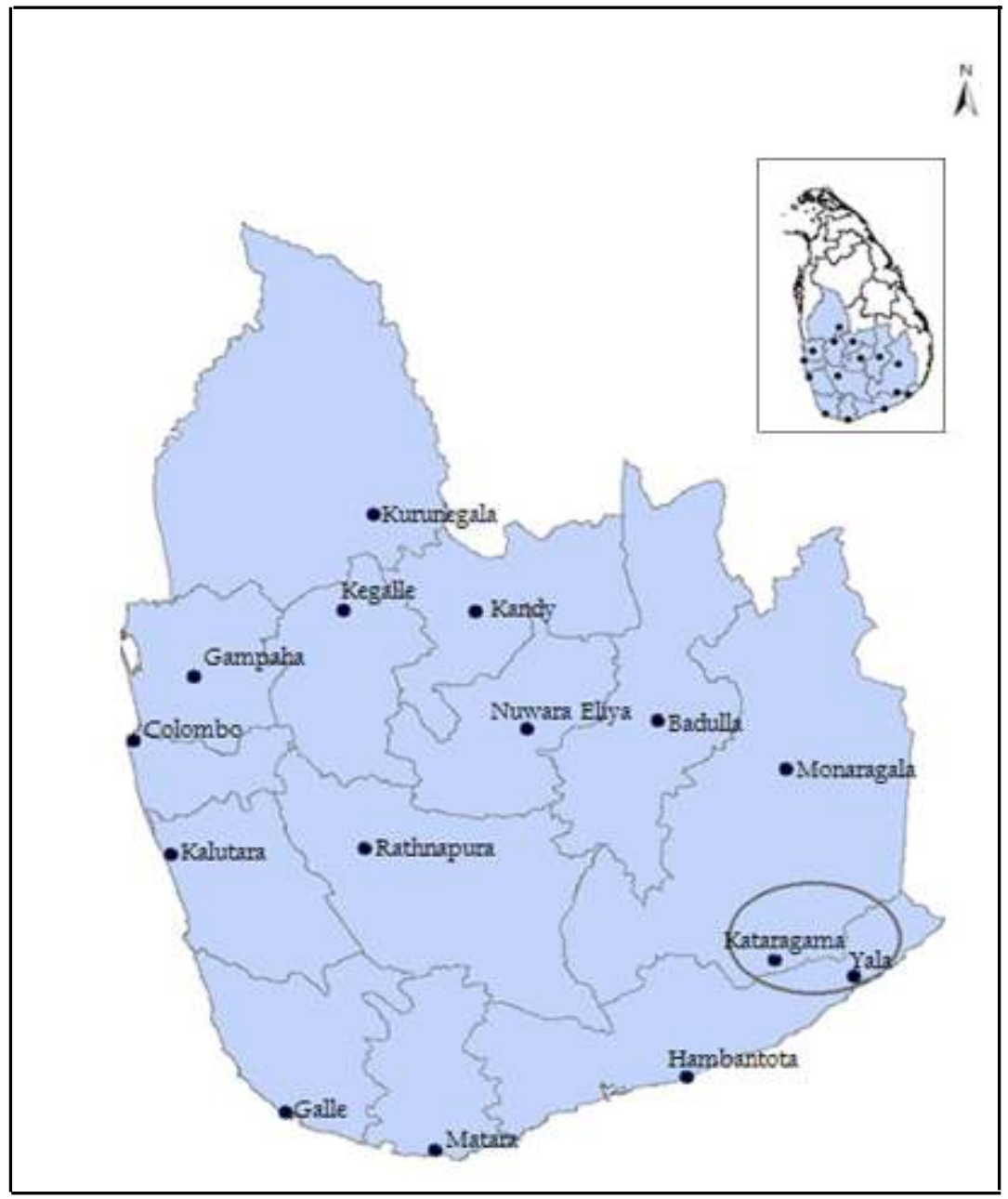

Figure 1: Map of the Study Locations

According to the survey the majority of the domestic tourists who visited Kataragama and Yala were from the Colombo district (Figure 2). It was 24\%. Gampaha and Kalutara districts were second and third with percentages of $18.5 \%$ and $12.5 \%$ respectively. The total percentage of the three districts of Gampaha, Kalutara and Colombo which represent the Western province was $55 \%$. The least number of arrivals were recorded from the districts of Monaragala and Nuwara Eliya. It was below 3\%. 


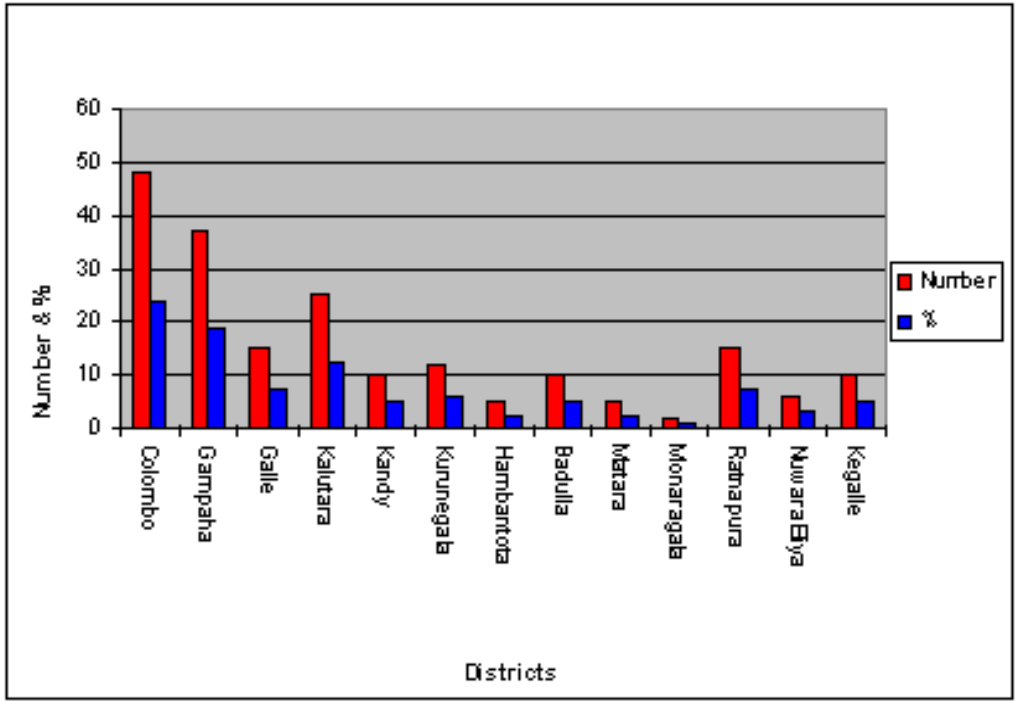

Figure 2: Domestric Tourist Arrivals by Districts

\section{Sex and Age}

The survey reveals that one hundred and seventeen or $58.5 \%$ of the domestic tourists of the sample were male while eighty three or $41.5 \%$ were female.

Sixty percent of domestic tourists according to the sample were in the age group of $30-49$ years. The youngest age group was 10 - 19 years with a percentage of 1.5. The percentage of the youth of the age group of 20- 28 was 17.5. The group above the age of 70 was seven of the total number amountingto $3.5 \%$ per cent (Figure 3 ).

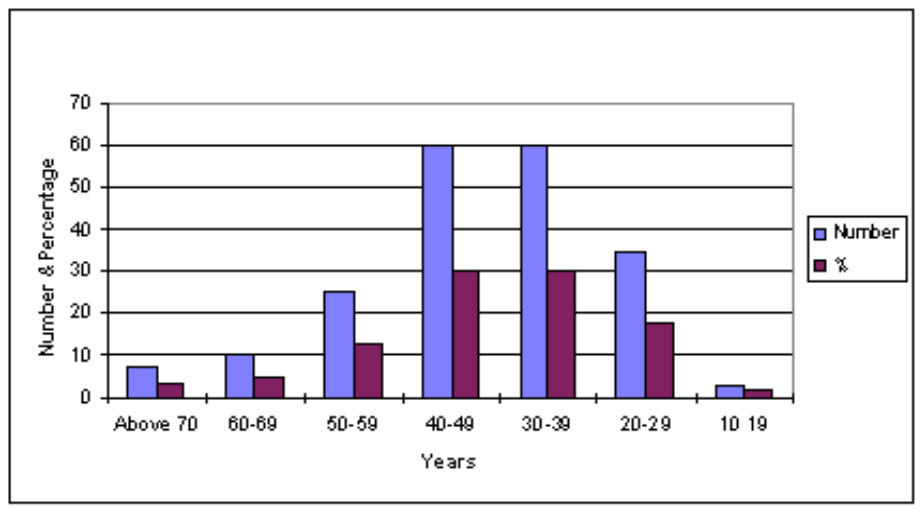

Figure 3: Domestic Tourist Arrivals by age 


\section{Education}

Out of two hundred in the sample seventy six were those who had passed the G.C.E. O/L(General Certification of Examination,Ordinary Level) accounting to $38 \%$, while sixty three or $31.5 \%$ of them had passed the G.C.E $\mathrm{A} / \mathrm{L}$ (Advanced Level). The most educated up to the degree level were forty or $20 \%$. There were 21 subjects who had studied up to grade five. It was $11 \%$.

\section{Occupation}

The majority of the domestic tourists were executives like managers, administrative officers, doctors and educationists. The total was 20\%. They were employed in the government and private sectors. Teachers and clerks in the non- executive level were $19.5 \%$ of total number. The skilled laborers like carpenters, drivers, masons and mechanics employed in the government, semi- government and private sectors were $16.5 \%$. Others in the sample accounting to $5.5 \%$ were pensioners like teachers, armed forces personnel, postal officers and other government and corporation officers. Most of the pensioners were teachers. The highest number of the sample was self- employed and private entrepreneurs. It was $23.5 \%$. Most of the businessmen visit Kataragama annually for religious purposes. The majority of the executives visit Kataragama and Yala for recreational purposes. Kataragama is a transit point for town dwellers who tour Yala and other places of interest in the south east dry zone tourist region. The school students were 15\%. They were accompanied by family members and the sole purpose of their tour was pleasure and education.

\section{Ethnic Groups}

Most of the domestic tourists were Sinhalese (Figure 4). It was $72.5 \% .20 \%$ were Tamils and 5\% were Muslims. Burghers and other races constituted $2.5 \%$.

Tourists mostly arrive during the Kataragama Perahera(procession) season in July - August. The Devalas(It is a place of worship for both Sinhalees and Tamils) hold special annual ritual activities during this period. Most of the subjects mentioned in the sample had visited Kataragama for religious and recreational activities. 


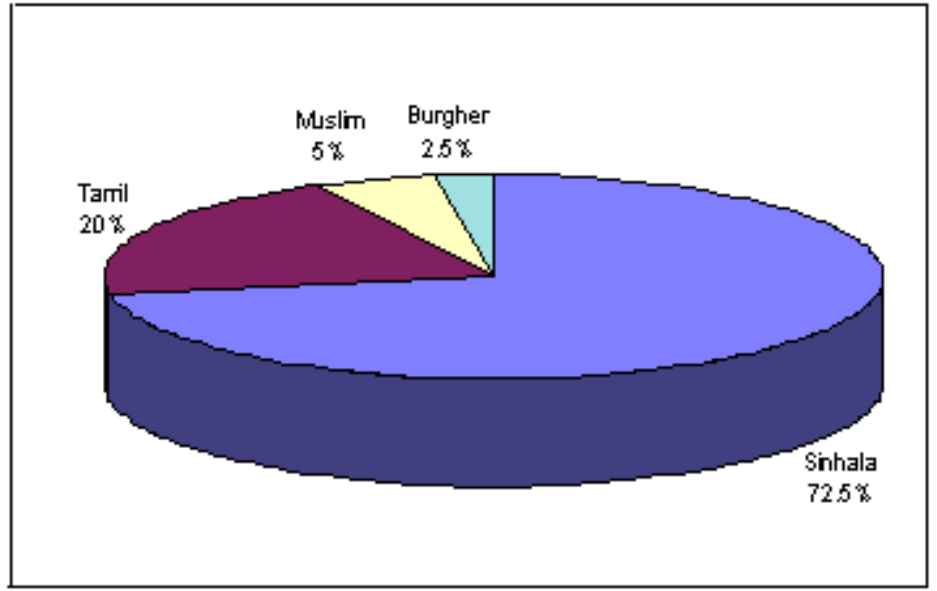

Figure 4: Ethnic Groups

\section{Mode of Transport}

The mode of transport of most of the tourists was hired vehicles (Figure 5). It was $47.5 \%$ of the total. Thirty seven per cent of the pilgrims used their own vehicles and arrived with family members. Thirteen per cent had used public transport. Motor cycles and bicycles were used by $2 \%$ of the sample.

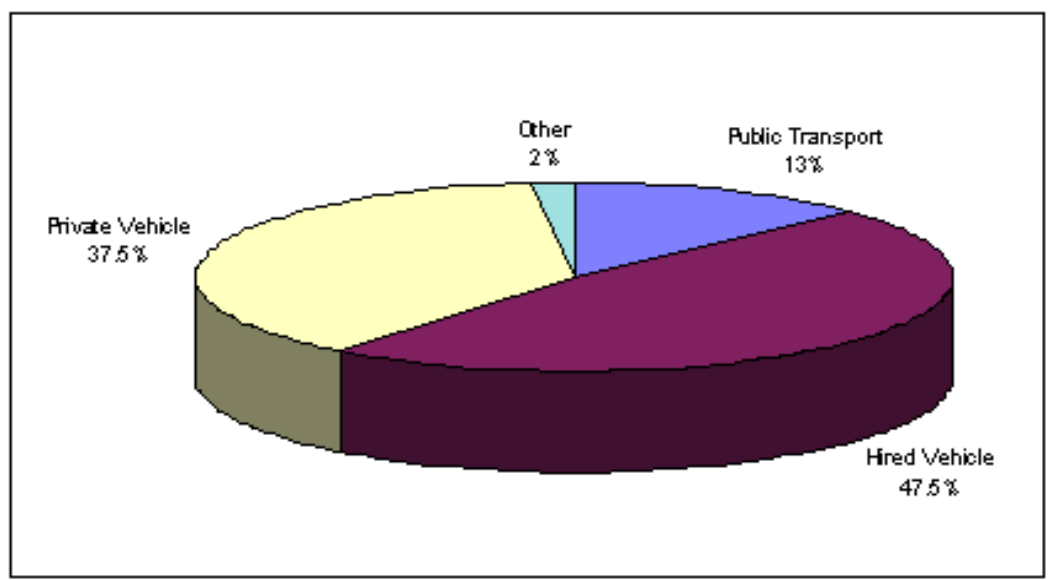

Figure 5: Mode of Transport

Fifty five per cent of domestic tourists had come with their family members, $25 \%$ with friends, $12 \%$ in-groups and 7.5 individual arrivals. 


\section{Purpose of Visit}

The main purpose of travel, as declared by the domestic tourists in the study area is religious (Figure 6). That is $52.5 \%$, whilst $37.5 \%$ of arrivals are relaxation and pleasure. Six per cent of domestic tourists and pilgrims visit this area, for the purpose of cultural and archeological interests. Visiting friends and relations and business purposes account for $1 \%$ for each.

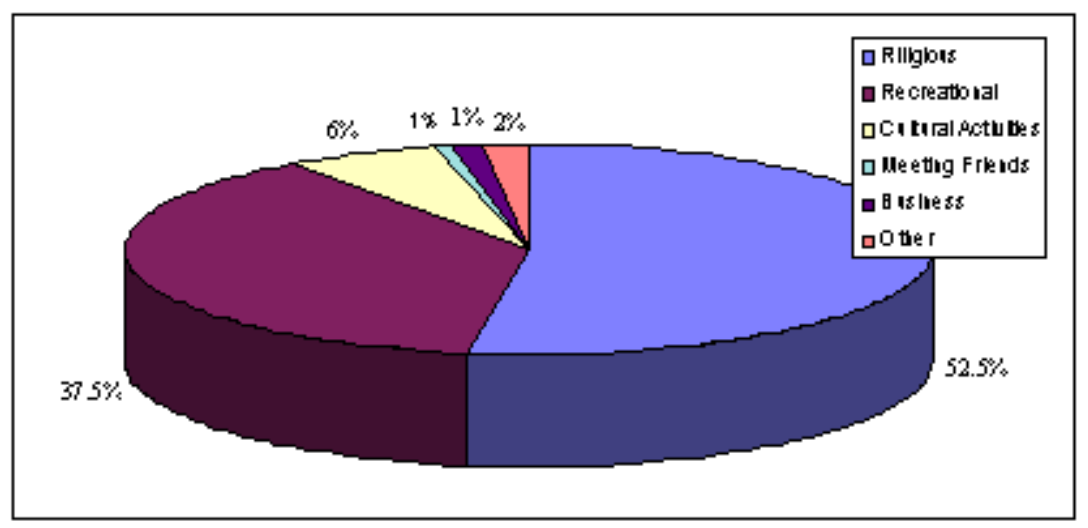

Figure 6: Purpose of Visit

\section{Duration of Stay}

The majority of tourists accounting for $62.5 \%$ stayed only a single night, 35 $\%$ stayed two nights and $2.5 \%$ stayed more than three days. The number staying one night in the study area was 125 with a percentage of 62.5 of the total.

\section{Proposal for a Tour Package to Cater to the Needs of Domestic} Tourists

More than $40 \%$ of the tourists in the sample were from the upper and middle- income groups. The visit to Kataragama and Yala was of much interest to them. A systematic tour service to cater to their needs at present is not available, thus creating the need for the introduction of a Tour Package that consists of the services of meals, accommodation and transport. Eighty per cent of the persons questioned were interested in purchasing such a tour package.

The new package should operate from all the main cities of the country. This would increase the tour attraction and create more enhanced facilities. A Tour Package to cover the Kataragama area for one day or two days including food, accommodation, and transport is required. It would definitely save 
time and energy for the tourists and reduce expenditure. The problem of traffic congestion in the town due to the arrival of groups of one or two persons could also be avoided.

The provision of food, accommodation and transport could be made at various rates thus catering to different groups with the introduction of various tour packages. This would contribute to the enhancement of the economic development of the area too. Presently, most of the tourists get their meals provided by the items brought from home. This has no effect on the economic progress of the area. The new process would avoid this situation and enhance progress in the sectors of hotels, accommodation and transport while increasing employment opportunities. In addition, there would be a comfortable service for the tourists and rapid development in tourist related industries.

With the establishment of parks, recreational clubs and reading rooms, there would be a creation of new employment opportunities and distribution of income. It is necessary to create services where the tourists would spend a higher amount of money rather than the low amounts they tend to spend at present. The condition would create industry- related employment, economic growth and enhancement of indirect government income.

The tourist institutes in the main cities should commence the sale of tour package services. They must mainly include the services of food, accommodation, transport and guide. Easy access to obtain them should be made available. The tour packages should include easy communication with the tourists through telephone or correspondence on the schedule and details of the tours according to the needs of the tourists.

\section{Preparation of a Domestic Tour Package for Southeast Dry zone Area}

It has been revealed that no local organisation or institution has introduced any organised tours. It is believed that people of all strata (levels) of society would like to purchase tour packages for their visits via southeast dry zone to Kataragama and Yala. Sample survey reveals that most of the domestic tourists who visit the study area are two- day tours. An example two- day tour itinerary is given below for the study area ( Table l). 
Table 1: Itinerary for proposed Tour Package for the Study Area 2days/1 night

\begin{tabular}{|l|l|}
\hline \multicolumn{2}{|l|}{ Day l } \\
\hline $6.00 \mathrm{am}$ & Leave from Colombo to Kataragama via Ratnapura, Embilipitiya \\
\hline $8.15 \mathrm{am}$ & Breakfast at Ratnapura \\
\hline $11.00 \mathrm{am}$ & Visit to Mahapelessa Hot Springs \\
\hline $1.00 \mathrm{pm}$ & Lunch \\
\hline $2.00 \mathrm{pm}$ & Visit to Tissamaharama Temple \\
\hline $3.00 \mathrm{pm}$ & At Kataragama \\
\hline $6.00 \mathrm{pm}$ & Participation of afternoon worship at Kataragama shrine \\
\hline $8.00 \mathrm{pm}$ & Dinner \\
\hline
\end{tabular}

\begin{tabular}{|l|l|}
\hline \multicolumn{2}{|l|}{ Day 2} \\
\hline $6.00 \mathrm{am}$ & Breakfast \\
\hline $6.30 \mathrm{am}$ & Leave for Yala National Park \\
\hline $8.00 \mathrm{am}$ & Visit Yala National Park \\
\hline $11.30 \mathrm{am}$ & Leave the National Park \\
\hline $1.00 \mathrm{pm}$ & Lunch \\
\hline $2.00 \mathrm{pm}$ & $\begin{array}{l}\text { Leave for Colombo via Matara, Veurukannala, Blow-holl and } \\
\text { Galle Fort }\end{array}$ \\
\hline $8.30 \mathrm{pm}$ & Colombo \\
\hline
\end{tabular}

(Meals, accommodation and type of transport are determined on the pasengers' income level). The tour package can be extended from a two to four day's trip in the vicinity area.

According to the survey three types of income groups of domestic tourists visit southeast dry zone area from Colombo.
a. High Income Groups (HIG)
b. Middle Income Groups (MIG)
c. Low Income Groups (LIG)

The usual pattern of travelling is using two routes to go to the study area and return to Colombo.

A cost estimate has been prepared according to the accepted method practised by travel agencies in Sri Lanka. Hence, 10\% mark up (profit) has been added to the total cost of the tour. The following items are included in the cost estimation of the tour package. 
Transport (cost per mileage)

Meals (full board or half board)

Accommodation Fee

Driver's Batta

Guide's Fee

Gate Fee

Jeep Charges and 10\% of Mark - up

Price of the Tour Package $=\frac{\text { Total Expenses of tour }}{\text { No. of Passengers }}$

Using the above method three types of tour packages have been identified from Colombo to Kataragama and Yala for various income groups ( Table 2).

Table 2: Estimated Package Prices for Domestic Tourists Two Day Tour Colombo to South East Dry Zone in 2007.

\begin{tabular}{|c|c|c|c|}
\hline $\begin{array}{c}\text { Name of the } \\
\text { Package }\end{array}$ & $\begin{array}{c}\text { Minimum No. of } \\
\text { Pax }\end{array}$ & Accommodation & Price per Pax \\
\hline HIG & 8 & A & Rs. 2900.50 \\
\hline MIG & 14 & B & Rs. 1677.20 \\
\hline LIG & 30 & C & Rs. 878.80 \\
\hline
\end{tabular}

Accommodation Categories
A = Air Conditioned Single Room
$\mathrm{B}=$ With Attached Bathroom
C $=$ Two Bedroom

A regression analysis is made here of the actual expenditure and its comparison with the anticipated expenditure by 141 domestic tourists for a single tour.

The Regression analysis is used to examine the present behaviour of expenses and the expected way of expenses in a tour package for a single tour by 141 Domestic tourists who were willing to purchase a tour package. The analysis forecasts the proportion of expenses of disposable income after the launch of a tour package for domestic tourists. 
A comparison of income and expenditure is made by the use of the two Regression Models. A simple regression model is made to estimate the relationship between disposable income and rational expenses of a tour incurred by the domestic tourists. The increase of expenses may depend on some other factors too such as market behaviour, the quality of accommodation, food, and transport people's attitudes.

Information is lacking to make a complex regressions model, which includes all the above factors. Hence, it is assumed all other factors are constant and only disposable income affects the amount of expenses of the tour.

A special evaluation based on income- expenditure analysis is made on the present level of this relationship and the level anticipated after the launch of a tour package. The following mathematical model was created on the basis of the analysis of income and expenditure. The least squared method was used to estimate these models.

Regression Model 1

$$
\mathrm{Y}_{\mathrm{p}}=\mathrm{b}_{0+} \mathrm{b}_{\mathrm{l}} \mathrm{X}+\mathrm{U}
$$

$\mathrm{Y}_{\mathrm{p}}=$ Present Expenditure on Tourism

$\mathrm{X}=$ Income

$\mathrm{b}_{0}=$ Intercept

$\mathrm{b}_{1}=$ Coefficient

$\mathrm{U}=$ Error

Regression Model 2

$$
\mathrm{Y}_{\mathrm{e}}=\mathrm{b}_{0+} \mathrm{b}_{\mathrm{l}} \mathrm{X}+\mathrm{U}
$$

$\mathrm{Ye}=$ Expected Expenditure after the launch of a tour package

$$
\begin{aligned}
& \mathrm{X}=\text { Income } \\
& \mathrm{b}_{0}=\text { Intercept } \\
& \mathrm{b}_{1}=\text { Slope } \\
& \mathrm{U}=\text { Error }
\end{aligned}
$$

The regression analysis results are presented in table 3 
According to the table 3, first model explains 54\% of the total variability while the second model explains more than $70 \%$ of the total variability. This implies that the second model is better than the first model. According to the correlation coefficient of both models, it indicates that there is a positive relationship between the variables of expected expenditure and income. According to the first model, the one rupee expenditure would result in 65 cents to the expenditure on tourism. After introducing a tour package to the system the one rupee expenditure would result in 92 cents to the expenditure on tourism in the study area. This clearly indicates that the absorption on tourism expenditure is highly benefited to the area; it multiplies income generation, employment creation and regional development.

Table 3: Summary of the Regression Models

\begin{tabular}{|l|c|c|}
\hline & $\begin{array}{c}\text { Model l } \\
\text { (P Value) }\end{array}$ & $\begin{array}{c}\text { Model 2 } \\
\text { (P Value) }\end{array}$ \\
\hline $\mathrm{b}_{0}=$ Intercept & 5.255 & 1.323 \\
\hline $\mathrm{b}_{1}=$ Slope & $\begin{array}{c}0.653 \\
(0.0008)\end{array}$ & $\begin{array}{c}0.927 \\
(0.0001)\end{array}$ \\
\hline $\mathrm{r}=$ Correlation Coefficient & 0.735 & 0.840 \\
\hline $\mathrm{R}^{2}=$ Coefficient of Determination & 0.541 & 0.707 \\
\hline
\end{tabular}

\section{Conclusion}

The study reveals that the South East Dry Zone Tourist Region is very popular among the foreign and domestic tourists in the period from July to December annually. Those domestic tourists and pilgrims visited from Western Province in the Island. Middle and high income groups are willing to buy the tour packages to cater to the study area. The tour package system is applied, the income generation; regional development and employment creation are highly absorb the study area.

The value of the coefficient of regression ( $\left.b_{1}\right)$ is 0.65 and 0.92 in the first and second models respectively. The first value reveals that only 65 cents of every rupee of expected expenditure is spent by a domestic tourist in the study area under the present conditions. The launch of a Tour Package will result in increasing the actual expenditure of a domestic tourist to 92 cents from every rupees of expected expenditure in the study area. This would result in economic benefits to the economy of the study area as a result of the introduction of a tour package. The systematic plan is necessary to the region with implementing proper programme with all the governmental and private agencies for the development of the tourism sector. 


\section{References}

Bhathiya, A.K. (1978) Tourism in India. New Delhi: Sterling Publishers Pvt. Ltd.

Bull, A. (1992) The Economics of Travel and Tourism. Melbourne: Pitman Publishing Ltd.

Central Bank of Sri Lanka. (2005) Annual Report- 2004. Colombo: Central Bank of Sri Lanka.

Francois, V. and Lionel, V. (1995) International Tourism. London: Macmillan Press Ltd.

Nakkawita, W. (1992) Tourism and Development. Colombo: Upali News papers Ltd.

Shantha, M.S. (2000) The Problems and Prospects of Domestic Tourism Sector in Sri Lanka. MA Thesis (Unpublished) Nugegoda: University of Sri Jayewardenepura.

Shantha, M.S. (2005) Enhancing Domestic Tourism in Kataragama and Yala Sri Lanka. v. 5 (1) Sabaragamuwa University Journal. pp. 17- 24.

UNDP/WTO. (1993) Ten Year Tourism Master Plan. Madrid: World Tourism Organization.

United Nations Conference on International Travel and Tourism in Rome, (1963) www.amazon.co.uk, Accessed 5 th of March 2008. 